S. N. NYECK

University of Amsterdam

\title{
CONTRACTING NATIONS OR STATUS NATIONS? EVIDENCE OF STRATEGIC BARGAINING IN NINETEENTH-CENTURY EAST AFRICA
}

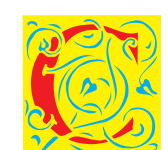

onventional wisdom with regard to the political and economic development of Africa gives weight to the colonial origin of the modern state and institutions. However, since the seventeenth century until World War I, African leaders entered into economic and political agreements with foreign firms, early transnational corporations, and signed procurement contracts for the delivery of various goods and services. These contracts present the theorist with an interesting challenge: where (if anywhere) do we place procurement practices in the history of state formation in Africa? I argue that by entering into contractual agreements of various kinds with their European-Asian counterparts, African leaders made it difficult to interpret subsequent changes in global trade and processes of state formation from the vantage point of imperialism and/or colonial interests only.

Drawing from various historical documents, ${ }^{1}$ the paper uses process tracing methods and analytic narratives to establish a relationship between historical contractual practices and state formation in the nineteenth-century East Africa. I trace the process through which local political leaders historically sought to secure monopolistic deals over trade with foreign entrepreneurs

1 A. J. Millette (ed.), Treaties in Force 1889-1971: Draft List of Treaties and Other International Agreements of Ethiopia, Addis Ababa, 1973. E. E. Seaton and S. T. Maliti, Tanzania Treaty Practice, Dar Es Salaam: Oxford University Press, 1973. S. Rubenson (ed.), Internal Rivalries and Foreign Threats 1869-1879, Acta Aethiopica, Vol. III, Addis Abeba: Addis Abeba University Press, 2000. S. Rubenson (ed.), Correspondence and Treaties 1800-1854, Acta Aethiopica, Vol. I, Addis Abeba: Addis Abeba University Press, 1987. 
through incomplete contracts for tangible economic goods (arms and slave trades, manufactured goods) and intangible political goods or services (security, knowledge, independence). By showcasing agents' bargaining strategies in contractual agreements, the paper sheds lights on notions of sovereignty and independence articulated through public contracting in Africa's political development.

Historical understanding of notions of independence and sovereignty by procurement practitioners in East Africa provides seeds for thought in controversial debate about government outsourcing today. Is outsourced sovereignty always threatening? ${ }^{2}$ Can we outsource sovereignty and remain independent? These are perhaps the most important conceptual queries that make East Africa's historical contractual experience pertinent today as new public-private partnerships for development, including government outsourcing, increasingly call for the use of private means to solve public problems in the developing countries. ${ }^{3}$

I argue that intangibles such as independence have historically been the return to polities contracting out services and goods from private suppliers. To the extent that historical evidence may help reframe the debate over the means and ends of development today, it is suggested that models of public-private partnerships that do not fundamentally secure the independence of the state in the long run may serve other purposes than development in Africa.

To better capture economic and political dynamics in East Africa and the ways in which contracting tangible and intangible goods transformed political and economic power, I have divided the coast into two sub-regions: the upper-northern region with Ethiopia (also known as Abyssinia in pre-modern era) as the most influential power, and the southern coast with Zanzibar as the leading political and economic broker. The name Abyssinia and Ethiopia are used interchangeably in historical documents scrutinized in this analysis. However, because data analyzed here mostly reflect transactions that took place in early nineteenth-century and beyond, I use the name Ethiopia throughout my anal-

2 P. R. Verkuil, Outsourcing Sovereignty: Why Privatization of Government Functions Threatens Democracy and What we Can do About it, Cambridge: Cambridge University Press, 2007. The author suggests outsourcing always threatens democracy because there is a fundamental link between sovereignty and democracy.

3 See for example the United Nations' Millennium Development Goals and the Post2015 Development Agenda calling for more partnership between the public and private sector for a sustainable development (https://goo.gl/VP4xD0 ), September 2014. 
ysis. Thus, data summarily capture the contractual transactions under emperor Tewodoros II (1855-1868), as well as during the reign of the briefly self-proclaimed Emperor Tekle Giyorgis II (1868-1872) upon the death of Tewodros, Yohannes IV (1872-1889), and Menelik II (1889-1913). First, I present the general strategic context in each sub-region and follow up with the analysis of disaggregated data to compare the contractual contexts, patterns, and strategic constraints of specific agents.

\section{The upper region}

In the nineteenth-century, the Abyssinian Empire (which roughly encompassed what is present day Ethiopia) appeared as the most internationally connected political entity in the northeastern region. Ethiopia's contractual practices rivaled those of old European kingdoms. For they were not just written in a local language (Amharic and Ge'ez), they also bore a particular aesthetic intended to showcase political power at its highest level of sophistication. Signatures, customized ornamental seals, the use of witnesses, a sophisticated diplomatic language, and a variety of styles leave no doubt in the reader's mind about the standing of Ethiopia as a great power among the greatest in this period. ${ }^{4}$ Ethiopia stood as the oldest known place in Africa to foreigners; its ancient Christianity amidst pagans and later Muslim neighbors was a highly symbolic currency that incentivized the Christian kingdoms of Europe and Asia to seek friendship for commerce and military reasons.

Ethiopia's contractual activities mostly took a bilateral form (Table 1.a. and 1.b.) with Italy, Great Britain, France, and the United States from roughly 1840 to 1914 . In the context of a long standing history of official negotiations with Europe, Ethiopia's history of public procurement of tangible and intangible goods and services shows that private (commercial and religious) entrepreneurs played a central role as brokers of trade contracts and land concessions. In all figures the vertical axis represents the number of contracts and the horizontal axis the year of the deal.

${ }^{4}$ S. Rubenson (ed.), Internal Rivalries and Foreign Threats 1869-1879. Acta Aethiopica, Vol. III. Addis Abeba: Addis Abeba University Press, 2000. S. Rubenson (ed.), Correspondence and Treaties 1800-1854. Acta Aethiopica, Vol. I. Addis Abeba: Addis Abeba University Press, 1987. 
- Section 2 - New Politics through the Lens of (Modern) History and Philosophy: S. N. Nyeck -

Table 1.a. Bilateral and multilateral contractual patterns of Ethiopia

Rows are levels of ET (Ethiopia)

Columns are levels of CP (contractual patterns [0] bilateral, [1] multilateral

$\begin{array}{llll} & 0 & 1 & \text { Total } \\ \text { ET } & 30 & 2 & 32 \\ \text { Total } & 30 & 2 & 32\end{array}$

Source: author's own calculations.

Table 1.b. Contingency table: Ethiopia's foreign partners. The main contracting parties were Italy, Great Britain, France, and the US. Belgium, Austria-Hungary and Germany were minor trade partners.
AUH $\quad$ BL $\quad$ FR $\quad$ GB $\quad$ GR IT US Total

$\begin{array}{lllllllll}\text { ET } & 1 & 1 & 9 & 8 & 1 & 10 & 2 & 32 \\ \text { Total } & 1 & 1 & 9 & 8 & 1 & 10 & 2 & 32\end{array}$

Source: author's own calculations.

Data reveal three peak years in economic and political diplomacy (Figure 1.1. below): First, 1876 after the British punitive expeditions of 1868 when Ethiopia was under Emperor Theodore II. Second, 1889 period marking the Mahdist invasion of Ethiopia (1887-89), the battle of Adwa (1896) where Ethiopians inflicted a monumental defeat to Italian troops, and the treaty of Addis Abeba securing Ethiopian independence under emperors Yohannes IV and Menelik II. Third and last was 1908, the year of the agreement defining the frontier between Ethiopia and the Italian colony, Eritrea, under emperor Menelik II.

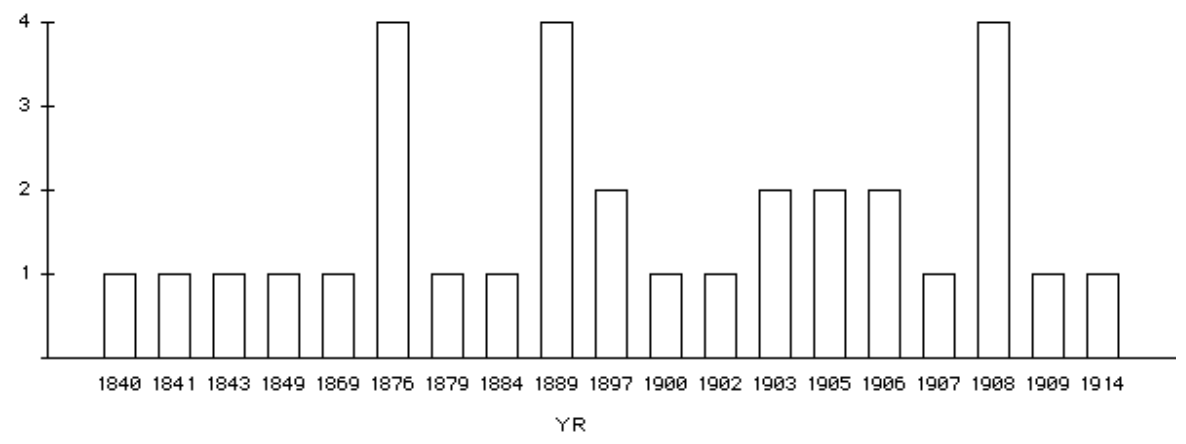

Figure 1.1. Contracting activities of Ethiopia by year (1840-1914)

$\mathrm{Y}=$ number of contractual agreements; $\mathrm{X}=$ Year.

Source: author's own calculations. 
The correlation between a high volume of contracting activities and Ethiopia's most important historical crises suggests the procurement of goods and services from suppliers took place in a politically stressful environment. Strategy and decisional processes in this context were not necessarily designed to foster economic self-sufficiency, but to preserve political independence; a pre-requisite to creating a lasting union as the country became more centralized.

Before its consolidation in the mid-nineteenth century, independent princes ruled Ethiopia ( - late 1700 s to 1855$)$. The country was united and centralized as a state under Emperor Tewodros around 1855. The consolidation of monarchical power was constantly contested by internal rebellion and external aggressions mainly from Egypt. At times Christianity helped promote peace; at other times, it worked against it. Thus, the project of national unity, the centralization of power, and the ambition to be taken seriously at the world stage made international cooperation and domestic coordination paramount to Ethiopia's survival. Starting in 1840, data capture the decisional motivation, the change in political values, and paradoxes of contractual choice in the context of state building when regional princes still had tremendous discretionary power over foreign exchanges.

\section{Ethiopia and France}

The Ethiopian case is useful in investigating the ways in which contracting historically transformed political power and institutions and the clash that ensued between collective monopolistic forces and individual aspirations. This struggle for decentralization and centralization is seen in the contractual activities and framing of transactions during the era of princes (1769-1855) "when the regional rulers held the real power in the country and the King of Kings in Gondar became but a puppet in the hands of his regents." Ethiopia used Christianity to finesse reputation among the Christian kingdoms of Europe especially with France. On 12 September 1840, a contract between "Sovereign Mahmud Hasan and Badri, judge and religious head, and Edmond Combes charged by the French government, Frederic Broquant, Legion of Honor," ${ }^{\text {f for }}$ the sale of the island of Kordumyat situated in modern day Eritrea, was signed.

5 M. Abir, Ethiopia: The Era of the Princes, Washington: Praeger, 1970, xxiii.

6 S. Rubenson (ed.), Correspondence and Treaties 1800-1854. Acta Aethiopica, Vol. I. Addis Abeba: Addis Abeba University Press, 1987, 46. 
In ceding to France a piece of land, the Ethiopian sovereign and judge made it clear that they were acting out of their "own free will." 7 Thee years later, a treaty of friendship was concluded between "Sahle Sillase, king of Shewa \& the Great Louis Philippe, king of France" for the peace of Jerusalem promising more preferential concessions. ${ }^{8}$ The Ethiopian kings in this case were regional princes.

The following year (June 16, 1876), ${ }^{9}$ Arnoux was given a political mandate as envoyé extraordinaire (extraordinary envoy) to friendly powers in Europe. If the free concession of a coal mine and land did not make sense in the beginning, it becomes clear why Menelik made the move. He wanted a non-state private ally and employed Arnoux with the hope of building a diplomatic front for the defense of Abyssinian interests. As Menelik's extraordinary envoy, Arnoux was granted the power to defend and protect the territorial integrity and independence of Abyssinia, sign a treaty with Egypt guaranteed by European powers, establish diplomatic and friendly relations with the Christian nations of Europe, raise questions about Egyptian aggression, and to explain the official position of Abyssinia to European powers. This strategy evidences the interdependence of trade and politics. More interestingly, it must be noted that the bundling of trade and politics was an African diplomatic initiative. From an Africanist perspective, Menelik could be seen as a visionary theorist and statesman who stretched the concept of freedom and independence.

\section{The southern region}

History has it that when Vasco da Gama reached the East Coast of Africa, he received "a friendly reception at Malindi [because] the ruler of that place was usually at war with his more powerful neighbor at Mombasa and accordingly welcomed the Portuguese as a possible ally." ${ }^{10}$ Through their strategic partner, the King of Malindi, the Portuguese later obtained a lease of the island of Mombasa, - which the African ruler had previously captured - and turned it into a center for proselytization. ${ }^{11}$ Mombasa therefore passed to the Portuguese and became their administrative capital.

\footnotetext{
7 S. Rubenson (ed.), Correspondence. Vol I., 36.

8 Ibidem, 66.

9 S. Rubenson (ed.), Internal Rivalries. Vol. III., 241, document 169.

10 J. Gray, Early Portuguese Missionaries in East Africa, St. Martin: Macmillan, 1958, 3.

11 J. Gray, Early Portuguese Missionaries in East Africa, chapter 4.
} 
In response to this attempt to capture and replace indigenous natural monopoly with a foreign "managed" control in gold trade, Africans allied themselves with pirates in North Africa to thwart Portuguese plans on the East Coast. Thus the configuration of the strategic context revealed a struggle between competing monopolistic claims; a struggle between the Cross and the Crescent. The Swahili sometimes invoked "Jihad" against infidels and eventually turned to Oman for support. In 1698 Mombasa fell to the Omanis who later established an independent Sultanate at Zanzibar in $1729 .{ }^{12}$

With the entry of the Omanis in the picture, the politics and economics of contracting became interplay between three types of agents separated by land and by sea, yet needing the produce from both sources: the landlocked, the coastal, and the Indian Ocean merchants. The Omani Sultanate at Zanzibar retained control over maritime commerce and secured the cooperation of the Sultans of the mainland by contracting out trade revenues. In the fragmented South at Kilwa, the Omanis "had made an agreement with the Sultan that he should retain his title and one-fifth of the customs dues." ${ }^{13}$ Zanzibar's contractual activities peaked around the years 1884 and 1885 followed by a steadily decline only after 1895 . This pattern suggests: (a) the influential role of the Indian Ocean slave trade in the making of Zanzibar's economy, (b) the position of the island as a full-fledged negotiator that colonial powers had to grapple with during the territorial scramble for Africa in late nineteenth-century.

\section{Intangibles: the rise of anti-slavery discourse and policy}

Data collected show Zanzibar's contractual transactions starting in the mid-nineteenth century when abolitionist discourse and policy were in full swing. Before the emergence of abolitionist discourse and policy, the most strategic concerns of different Arab families in East Africa were the consolidation and preservation of their

12 J. Middleton, African Merchants of the Indian Ocean: Swabili of the East African Coast, Long Grove: Waveland, 2004, 35-36. The date varies from different sources. The Sultanate, however, became consolidated only after the defeat of the Portuguese in Mombasa in 1832. The actual transfer of the independent Omani Sultanate from Muscat to Zanzibar took place around 1861; see E. E. Seaton and S. T. Maliti, Tanzania Treaty Practice, Dar Es Salaam: Oxford University Press, 1973, 5.

13 C. S. Nicholls, The Swahili Coast: Politics, Diplomacy and Trade on the East African Littoral, 1798-1856, New York: Africana Publishing Corporation, 1971, 33. 
independence from Oman. Politics before early nineteenth-century was therefore dominated by internal feuds between the houses of Mazrui, the pro-independence faction, and the Busaidi in favor of continuing allegiance to Oman. After establishing themselves at Zanzibar in late eighteenth century, the authority of the Mazrui continued to be challenged from Oman and from the mainland.

With the demise of the Portuguese in the region, a strategy was devised to contract out independence with Britain stationed at Bombay in India. A letter by Abdulla bin Ahmed sent to Bombay explained that "he was the ruler of an independent state which Said bin Sultan of Oman wished to annex" 14 and declared that he would rather give the said independent state to England. This request was rejected given the close ties that bound Britain and Oman. Notwithstanding this complication, the Mazrui amended their offer by giving "half of [their] revenues"15 to Britain in exchange for an officer stationed on the coast. The British never formally accepted the offer but changes in discourse over trade practice and policy made their presence in the region necessary. Instead of working with critics stationed at Mombasa, Bombay made the choice to cooperate with Sultan Seyyid Said in Oman who regained control of the East African coast in early nineteenth-century after turning local protests against the Mazrui family to his advantage.

In 1807 the British adopted the Slave Trade Act, which outlawed slave trade in all territories and dominions. Previous attempts to curb the slave trade yielded imperfect results in East Africa the reason being that the Sultan of Oman derived substantial revenues from taxes levied on slave ships from Zanzibar. French merchants at Mauritius and Bourbon islands had independently secured slave trade concessions with Zanzibar and Kilwa in 1776, 1785, and $1819,{ }^{16}$ and they were competing with Portuguese and Spanish merchants. To win the collaboration of Oman, the British strategically likened the slave trade to piracy, which they previously fought alongside Seyyid. The reinvention of an anti-piracy discourse in the forms of a fight against slavery offered the discursive incentive to the Sultan of Oman to agree to a treaty with Moresby in 1822. Given the economic return of the slave trade from Zanzibar to the Omani treasury, this political discourse proved strategically significant because the treaty had effect in Zanzibar where the Omani had previously migrated.

14 J. Gray, Early Portuguese Missionaries in East Africa, St. Martin: Macmillan, 1958, 21.

15 Ibidem, 21.

16 C. S. Nicholls, The Swahili Coast: Politics, Diplomacy and Trade on the East African Littoral, 1798-1856, New York: Africana Publishing Corporation, 1971, 198, 131-36. 
The Omani edict of 1850, when the contractual history of Zanzibar starts in my sample, forbade slave trading to Indians merchants on the East African Coast leading to, on one hand, the consolidation of Zanzibar authority in the sub-region, and on the other hand, increase in slave capture for local plantation industry. ${ }^{17}$ But Sultan Seyyid Said's double-dealings with the slave trade and pirates quickly led some colonial administrators to reconsider the offer from the Mazrui family, as well as new partnerships with other groups in the hinterland.

Africans bargaining opportunities and choice of contracting partners became more restricted in late nineteenth-century, thanks to the outright scramble of the continent. Nevertheless, the use of contracts as instruments of cooperation and non-cooperation points to something else in East Africa: a progressive attempt to harness the winds of discontent. To illustrate, political contracts between coastal dwellers and the hinterland with Britain and Germany pulled in and pushed away power from Zanzibar simultaneously. In the year leading to the conference of Berlin in 1885, British negotiators secured treaties with the chiefs Chagga and Taveta in the presence of Sir J. W. Matthews, in which they recognized their loyalty to the Sultan of Zanzibar. Conversely, German treaties signed with many chiefs from the mainland and hinterland tended to disavow Zanzibar's supremacy.

Analyzed from the perspective of European possessions, these historical dealings have mainly been seen as colonial. Nineteenth century swapping of trade and political status between public and private agents ended with the consolidation of a colonial regime. Nevertheless, when one examines the motivational processes and tactical choices from an Africanist perspective, it becomes probable that theory, not the action of the parties, might be at fault here. Scholars have not seen the pedagogical, value-laden relevance of the seemingly subpar African choice in colonial encounters because rational choice assumptions confound strategy with choice and sovereignty with independence.

17 C. S. Nicholls, The Swahili Coast, New York: Africana Publishing Corporation, 1971, $211-15$. 